\title{
Clinical and radiographic evaluation of double pelvic osteotomy to treat canine hip dysplasia
}

\section{Leandro Santos Lopes $^{1^{*}}$ André Luis Selmi ${ }^{2}$ Bruno Testoni Lins ${ }^{3}$ Aline Schafrum Macedo ${ }^{1}$}

\author{
${ }^{1}$ Faculdade de Medicina Veterinária e Zootecnia (FMVZ), Universidade de São Paulo (USP), Av. Prof. Orlando Marques de Paiva 87, Vila \\ Universitária, São Paulo, SP, 05508-270, Brasil. E-mail: vetleandrolopes@gmail.com. .Corresponding author. \\ ${ }^{2}$ Hospital Veterinário Anhembi Morumbi, Rua Conselheiro Lafaeite, 64, Brás, São Paulo, SP, Brasil. \\ ${ }^{3}$ OrtoDerm Especialidades Veterinárias, Rua Demóstenes, 468, Campo Belo, São Paulo, SP, Brasil.
}

\begin{abstract}
The purpose of this study was to describe our initial experience with double pelvic osteotomy (DPO) in young dogs affected by hip dysplasia (HD) and to report their postoperative outcome. Seven dogs (four females and three males) were included in our study with mean age 8.3 ( \pm 1.7$)$ months, and mean body weight $29.5( \pm 7.4) \mathrm{Kg}$. Breeds involved were: Rottweiler $(n=1)$, Labrador Retriever $(n=3)$, Golden Retriever $(n=1)$, Great Dane $(n=1)$ and São Miguel Cattle Dog $(n=1)$. The most common history complaints were: pelvic limb lameness and pain at hip extension and hip abduction. All surgical procedures consisted of osteotomy of the ilium and pubis, acetabular ventroversion and iliac stabilization with a customized bone plate with seven screws, four screws placed at the cranial fragment and the remaining three in the caudal aspect. Average surgical time was 65.8 ( \pm 10.4$)$ minutes and median follow-up assessment was $68( \pm 15)$ days. Fracture healing was observed within mean period of $26.3( \pm 8.9)$ days. Six patients $(86 \%)$ had satisfactory outcome and one patient didn't improve after surgery and had to undergo a total hip replacement. Our results showed that DPO is an effective treatment for HD due to the preservation of pelvic geometry and low postoperative morbidity. Since it is a recent technique, further studies are recommended. Key words: double pelvic osteotomy, hip dysplasia, acetabular ventroversion.
\end{abstract}

Avaliação clínica e radiográfica da osteotomia dupla da pelve no tratamento da displasia coxofemoral canina

RESUMO: O objetivo do estudo é a descrição da osteotomia dupla da pelve (ODP) em pacientes com displasia coxofemoral (DCF) e relatar a evolução pós-operatória. As raças acometidas foram: Rottweiler $(n=1)$, Labrador $(n=3)$, Golden Retriver $(n=1)$, Dogue alemão $(n=1)$ e Fila de São Miguel $(n=1)$. O total foi de sete animais, sendo três machos e quatro fêmeas; a média de idade e peso dos cães foi de $8,3 \pm 1,7$ meses e 29,5 7,4Kg, respectivamente. As queixas iniciais mais comuns antes da cirurgia foram: claudicação em membro pélvico e dor à extensão e abdução do quadril. A cirurgia constou em realizar a osteotomia do ílio e púbis, rotacão axial do acetábulo sobre a cabeça do fêmur e osteossíntese do ílio com a utilização de placa fixada com sete parafusos, quatro destes no segmento cranial e três no segmento caudal. Após a cirurgia um animal não apresentou melhora do quadro, caracterizado por agravamento da subluxação coxofemoral, sendo submetido à prótese total de quadril. O tempo médio de cirurgia foi de 65,8土10,4 minutos e o periodo de acompanhamento médio pós operatório foi de $68,0 \pm 15,0$ dias, visibilizando a reação osteoproliferativa no foco de osteotomia iliaca em um periodo médio de 26,3土8,9 dias. Dos sete animais envolvidos no estudo, seis tiveram recuperação satisfatória após o primeiro procedimento no período avaliado. Os resultados apontam a técnica de OPD como procedimento eficiente no tratamento de DCF devido à preservação da geometria pélvica e baixa morbidade pósoperatória. Por se tratar de uma recente técnica, ainda pouco difundida, é interessante a realização de maiores estudos.

Palavras-chave: osteotomia pélvica dupla, displasia coxofemoral, ventroversão acetabular.

\section{INTRODUCTION}

Hip dysplasia (HD) is a common orthopedic disease that affects mainly median and large breed dogs and is characterized by subluxation of the coxofemoral joint (hip laxity) with subsequent degenerative changes manifested by pain and lameness
(TOMLINSON \& COOK, 2002). Treatment options are conservative or surgical treatment. Medical management consists on the administration of nonsteroidal anti-inflammatory drugs, chondroprotective drugs and weight maintenance. Surgical treatment is divided into a range of procedures such as femoral head osteotomy, total hip replacement, triple pelvic 
osteotomy (TPO) in early cases (MANLEY et al., 2007), juvenile pubic symphysiodesis (JPS) (DUELAND, 2001; PATRICELLI, 2002) and more recently double pelvic osteotomy (DPO) (VEZZONI et al., 2010).

DPO, as well as TPO and JPS are indicated to young dogs, since they tend to minimize or avoid the development of degenerative joint disease due to the ventroversion of the dorsal acetabular rim and to increase cover of femoral head (SLOCUM, 1992; VEZZONI et al., 2010).

The technique was first described as just iliac and pubic osteotomy, without the ischium, and resulted in acetabular ventroversion with lateral rotation of the ilium and ischium torsion and deformity. The idea of this new technique was to simplify TPO and reduce complication rates and morbidity, because, despite its effectiveness, TPO has high complications rates (VEZZONI et al., 2010).

An ex vivo study in dogs compared DPO to TPO and showed that the acetabular ventroversion obtained after DPO is $5^{\circ}$ lower than that obtained by TPO, showing that DPO is a viable option (PUNKE et al., 2011). VEZZONI et al. (2010) have demonstrated that DPO resulted in marked Norberg angle and femoral head coverage improvement in young dogs, and is associated with low complication rate, despite the fact that requires greater surgical ability due to limited rotation of the acetabular segment.

The purpose of this study was to describe the initial clinical and radiographic findings and complications after DPO in seven dogs with HD.

\section{MATERIALS AND METHODS}

All patients included in the study were attended at a university veterinary hospital in the city of São Paulo. The inclusion criteria were: age between 6 and 12 months, positive for HD as confirmed by pain at hip extension and positive Ortolani sign, and also radiographic findings of coxofemoral subluxation without advanced degenerative joint disease (as periarticular osteophytes or changes in the femoral head contour).

Data was compiled considering breed, gender, body weight and affected limbs. Reduction angle (RA) and subluxation angled (AS), during the Ortolani maneuver, were determined by filming and subsequent measurement of the obtained image by goniometer; Maximum degree of hip flexion and extension were measured by goniometer applied directly over the hip joint, the fixed arm was arranged over the pelvic axis and the movable arm arranged over the femoral axis, with the center of rotation positioned over the target joint (JAEGGER et al., 2002); Range of motion (ROM) was determined by subtracting hip extension and flexion values. Thigh perimeter (TP) was determined by an inelastic tape measure in the middle third of the operated leg (BAKER et al., 2010). Lameness scale was determined as absent, discrete, moderate or marked. All clinical variables were determined in both legs immediately before and after surgery, and in the first and third months postoperatively. The Norberg angle (NA) and percentage coverage of the femoral head (PCFH) were determined preoperatively, immediately after surgery and after three months, both in the operated and non-operated leg.

DPO was performed with the patient in lateral recumbency, with the target leg dorsally. After prepped, the leg was abducted to approach the pubic segment with dissection and preservation of the insertion of the pectineus muscle, followed by approximately one centimeter pubic ostectomy near the medial aspect of the acetabulum. The first patient underwent pubic osteotomy and not ostectomy. All soft tissues were approximated with a running suture with 25 polyiglecapone and subcutaneous tissue was sutured with simple interrupted pattern with polyamide. Later, an approach to the iliac body was performed, followed by iliac osteotomy, caudal to the sacrum body, with about $20^{\circ}$ of inclination to the long axis of the ilium. Bone fixation was performed in all patients with a $30^{\circ}$ of rotation bone plate with cortical screws; All soft tissues were approximated in the same manner.

\section{RESULTS AND DISCUSSION}

Seven patients were included, three males and four females of the following breeds: one Rottweiler, three Labrador Retrievers, one Golden Retriever, one Great Dane and one São Miguel Cattle Dog. Mean age was 9.6 \pm 2.7 months and mean body weight was $49.5 \pm 13.4 \mathrm{~kg}$. Mean surgical time was $65.8 \pm 10.4$ minutes.

The only trans-operative complication was the difficulty to rotate the caudal acetabular rim due to osteotomy and not ostectomy of the pubic segment in a single patient. Such difficulty is related to the maintenance of the ischial segment, as already reported by VEZZONI et al. (2010), even when performing pubic ostectomy.

Acetabular rotation in DPO results from ischial deformation and possible torsion in the pubic symphysis in growing dogs, and such assumption has been confirmed by PUNKE et al. (2011), where in fact, 
the acetabular ventroversion resulted from the pubic symphysis rotation. So it is plausible to affirm that the difficulty in this case occurred due to the skeletal maturity of the operated dog, since the calcified symphysis would not allow adequate acetabular ventroversion, besides that the pubic osteotomy in the acetabulum's medial aspect, instead of an ostectomy, favored the contact of the sectioned surfaces of the pubis that limited the segment's rotation due to contact. Although, VEZZONI et al. (2010) reported that acetabular rotation can be facilitated by sectioning the sacrotuberous ligament, this maneuver was not considered necessary to the other dogs of this study. The possible changes from the desmotomy associated to DPO have not yet been demonstrated in dogs; however, the procedure should be considered with caution. In our cases, despite the restriction imposed by the integrity of the ischium and the sacrotuberous ligament and the possible limitation of deformation of the pubic symphysis, proper implant positioning on the cranial bone segment was only obtained after the plate was fixed due to the traction made by the cortical screws.

Six of the seven patients of this study had satisfactory recovery after the procedure and were bearing weight 24 hours postoperatively, with progressive lameness decrease in the following three months. None of the dogs displayed any signs of discomfort in the operated leg. The only patient that didn't show a successful outcome was subsequently submitted to total hip replacement, and was then removed from the study.

Despite clinical improvement, maximum degree of hip flexion and extension and resulting ROM were stable in the first and third month's postoperative evaluations for both legs. Some factors may have contributed to these results such as patient selection, since dogs with signs of pain and lameness, but few degenerative hip joint disease and proper hip ROM, were included in this study. Similarly, TP increased in both legs; however, this increase was not significant, and may be related to body growth during the evaluation period, and not as a result of better weight bear after surgery.

All dogs displayed positive Ortolani sign prior and after surgery. The mean RA at the preoperative period was $34.5 \pm 19.0^{\circ}$, and gradually decreased in the post-operative evaluations time.
In the same way, mean SA was $13.5 \pm 7.0^{\circ}$ at the preoperative evaluation and remained similar at subsequent evaluation moments (Table 1). These findings are similar to the descriptions of MANLEY et al. (2007) and VEZZONI et al. (2010) after TPO and DPO, respectively, in young dogs with dysplasia.

Corrective pelvic osteotomies intend to improve contact between the femoral head and the acetabulum, as demonstrated by DEJARDIN et al. (1998), TOMLINSON \& COOK (2002) and VEZZONI et al. (2010). However, MANLEY et al. (2007) didn't report improvement in joint stability in dogs submitted to TPO. Although, significant improvement was observed in PCFH and NA after DPO in the dogs of this study (Table 2), as already described by VEZZONI et al. (2010) after DPO and by TOMLINSON \& COOK (2002) after TPO, such results should be carefully analyzed. Progressive rotation of the acetabulum rim on the femoral head, after TPO, promotes better articular fit, but no greater joint contact (DEJARDIN et al., 1998) but DPO's result on this variable is not described in the literature. Similarly, comparison between 20 and $30^{\circ} \mathrm{TPO}$ plates in dogs with hip dysplasia revealed that, despite significant improvement in joint congruency after surgery, there was similarity in the values of PCFH and NA (TOMLINSON \& COOK, 2002), denying the need of excessive ventroversion.

It is reasonable to say that the interpretation of the values of RA, SA, PCFH and NA in this study should be analyzed altogether. And also that the significant improvement of the radiographic articular congruency does not reflect better clinical hip stability after DPO, since Ortolani sign remained positive in all patients (despite numerical decrease in both RA and SA). Since RA is predominantly associated with the degree of joint laxity and SA is related to the dorsal acetabular edge angle (SLOCUM, 1998), it can be inferred that DPO does not affect joint instability; although it may possibly decrease the dorsal acetabular edge angle, decreasing instability but not removing it. This hypothesis is based on the findings of MANLEY et al. (2007) who demonstrated that TPO improved dorsal acetabular edge angle in dogs with dysplasia but did not alter the rate of radiographic distraction in this same group of dogs.

Table 1 - Mean \pm standard deviation reduction angles (RA) and subluxation angles (SA) in dogs with hip dysplasia that underwent double pelvic osteotomy.

\begin{tabular}{lcccr}
\hline & Preoperative & Immediate Postoperative & 30 days & 90 days \\
RA & $34.5 \pm 19.0^{\circ}$ & $32.5 \pm 17.5^{\circ}$ & $32.0 \pm 17.0^{\circ}$ & $32.5 \pm 16.5^{\circ}$ \\
SA & $13.5 \pm 7.0^{\circ}$ & $13.0 \pm 6.0^{\circ}$ & $13.5 \pm 6.5^{\circ}$ & $13.5 \pm 6.0^{\circ}$ \\
\hline
\end{tabular}

Ciência Rural, v.48, n.4, 2018. 
Table 2 - Mean \pm standard deviation percentage coverage of the femoral head (PCFH) and Norberg angle (NA) in dogs with hip dysplasia that underwent double pelvic osteotomy.

\begin{tabular}{lccc}
\hline & Preoperative & Immediate Postoperative & 90 days \\
PCFH & $58.9 \pm 2.3 \%$ & $63.4 \pm 2.8 \%$ & $68.4 \pm 3.2 \%$ \\
NA & $99.0 \pm 3.5 \%$ & $102.0 \pm 4.0 \%$ & $106.5 \pm 2.0 \%$ \\
\hline
\end{tabular}

PUNKE et al. (2011) reported that the $25^{\circ}$ DPO plates promoted similar ventroversion to the $20^{\circ}$ OTP plates, but the authors do not mentioned other variables such as PCFH and NA. In this study, $30^{\circ}$ plates were used, without suggestive signs of excessive femoral head rotation, since the postoperative acetabular coverage was approximately $65 \%$, values similar to those reported by VEZZONI et al. (2010); although, with different plates and angulations.

\section{CONCLUSION}

Despite the small number of patients submitted to the DPO technique in this study, the procedure proved to be a viable alternative for the treatment of young dogs affected by $\mathrm{HD}$, as it resulted in increased acetabular coverage of the femoral head, decreased joint instability and remission of clinical signs.

\section{BIOETHICS AND BIOSECURITY COMMITTEE APROVAL}

The authors of the paper entitled "Clinical and radiographic evaluation of double pelvic osteotomy to treat canine hip dysplasia" declare that, as a series of case reports, the procedures that originated the reported data were not submitted to approval of the University's Ethics Committee because they were not enrolled in a controlled study nor trial. We declare awareness of the content of resolutions from the Conselho Nacional de Controle de Experimentação Animal (CONCEA) involving animals. As such, the authors take full responsibility for the data presented in this paper. The authors are available for possible queries, if the competent authorities shall require such.

\section{ACKNOWLEDGEMENTS}

The authors declare no conflict of interest and that no funding was provided for this study.

\section{REFERENCES}

BAKER, SG. et al. Comparison of four commercial devices to measure limb circumference in dogs. Veterinary and Comparative Orthopedics and Traumatology, v.23, n.6, p.406-410, 2010. Available from: $<$ https://vcot.schattauer.de/contents/archivestandard/ issue/1179/issue/special/manuscript/13584/show.html>. Accessed: Jan. 05, 2016. doi: 10.3415/VCOT-10-03-0032.
DEJARDIN, LM. et al. The effect of triple pelvic osteotomy on the articular contact area of the hip joint in dysplastic dogs: an in vitro experimental study. Veterinary Surgery, v.27, n.3, p.194-202, 1998. Available from: $<$ http://onlinelibrary.wiley.com/doi/10.1111/ j.1532-950X.1998.tb00118.x/full>. Accessed: Jan. 29, 2016. doi: 10.1111/j.1532-950X.1998.tb00118.x.

DUELAND, RT. et al. Effects of pubic symphysiodesis in dysplastic puppies. Veterinary Surgery, v. 30, p. 201-217, 2001. Available from: <https://www.ncbi.nlm.nih.gov/pubmed/11340551>. Accessed: Feb. 15, 2016. doi: 10.1053/jvet.2001.23350.

JAEGGER, G. et al. Reliability of goniometry in Labrador Retrievers. American Journal of Veterinary Research, v.63, n.7, p.979-986, 2002. Available from: <https://www.ncbi.nlm.nih.gov/pubmed/12118679>. Accessed: Aug. 30, 2015. doi: 10.2460/ajvr.2002.63.979.

MANLEY,PA. etal.Long-term outcome of juvenile pubic symphysiodesis and triple pelvic osteotomy in dogs with hip dysplasia. Journal of the American Veterinary Medical Association, v.230, n.2, p.206-210, 2007. Available from: <https://www.ncbi.nlm.nih.gov/pubmed/17223752>. Accessed: Oct. 26, 2015. doi: 10.2460/javma.230.2.206.

PATRICELLI, AJ. et al. Juvenile pubic symphysiodesis in dysplastic puppies at 15 and 20 weeks of age. Veterinary Surgery, v. 31, n.5, p. 435-444, 2002. Available from: <https://www.ncbi. nlm.nih.gov/pubmed/12209414>. Accessed: Nov. 11, 2015. doi: 10.1053/jvet.2002.34766.

PUNKE, JP. et al. Acetabular ventroversion with double pelvic osteotomy versus triple pelvic osteotomy: A cadaveric study in dogs. Veterinary Surgery, v.40, n.5, p. 555-562, 2011. Available from: $<$ https://www.ncbi.nlm.nih.gov/pubmed/21361986>. Accessed: Nov. 29, 2015. doi: 10.1111/j.1532-950X.2011.00802.

SLOCUM, B.; SLOCUM, T.D. Pelvic osteotomy for axial rotation of the acetabular segment in dogs with hip dysplasia. Veterinary Clinics of North America: Small Animal Practice, v.22, n.3, p.645-682, 1992. Available from: <https://www.sciencedirect. com/science/article/pii/S0195561692500614>. Accessed: Jan. 18, 2016. doi: 10.1016/S0195-5616(92)50061-4.

TOMLINSON, JL.; COOK, JL. Effects of degree of acetabular rotation after triple pelvic osteotomy on the position of the femoral head in relationship to the acetabulum. Veterinary Surgery, v.31, n.4, p.398-403, 2002. Available from: <http://onlinelibrary.wiley. com/doi/10.1053/jvet.2002.33598/full>. Accessed: Jun. 04, 2015. doi: $10.1053 /$ jvet.2002.3359.

VEZZONI, A. et al. Double pelvic osteotomy for the treatment of hip dysplasia in young dogs. Veterinary and Comparative Orthopedics and Traumatology, v.23, n.6, p.444-452, 2010. Available from: $<$ https://www.ncbi.nlm.nih.gov/pubmed/20830453>. Accessed: Dec. 12, 2015. doi: 10.3415/VCOT-10-03-0034. 